\title{
Evaluation of Heavy Metal in Coastal Water at Kelantan
}

\author{
Rizki Wannahari, Nurul Ain Abdullah, \\ Mariam Firdhaus Mad Nordin and Marinah Muhammad
}

Departement of Environmental Technology, Faculty of Agro Based Industry, Jeli Campus, Universiti Malaysia Kelantan, Locked bag 100, 17600, Jeli, Kelantan, Malaysia

Received 2013-06-12; Revised 2013-09-10; Accepted 2014-01-20

\begin{abstract}
Five sites were selected representing the studied sites of the coastal water in Kelantan, Malaysia during 1996 until May 2012. These selected sites are the popular beaches in Kelantan which are Sri Tujuh Beach (STB) located in Tumpat region, Cahaya Bulan Beach (PCB) and Sabak Beach (SB) in Kota Bharu region, Irama Beach (PI) in Bachok region and Bisikan Bayu Beach (PBB) in Pasir Putih region. In other to identify the quality of coastal water in this five popular coasts along Kelantan, study of heavy metals contamination in coastal water has been done. Evaluation of heavy metal contamination in Kelantan coastal water has doing by combine the data from Department of Environment (DOE) Malaysia and the data was got from this research. There are four types of heavy metal concentration has evaluated in this research; Cadmium $(\mathrm{Cd})$, Cupper $(\mathrm{Cu})$, Lead $(\mathrm{Pb})$ and Chromium $(\mathrm{Cr})$. From this evaluation, we can see the fluctuation of concentration the four type heavy metal $(\mathrm{Cd}, \mathrm{Cu}, \mathrm{Pb}, \mathrm{Cr})$ from 1996 until May 2012. Most of the year, the concentration of heavy metal is between the range of Malaysia marine quality standard except for Lead. Lead was proven to be the highest concentration pollutant in the five beaches in certain time and also exceed the Malaysia marine standard.
\end{abstract}

Keywords: Evaluation, Coastal Water, Kelantan, Heavy Metal, Standard

\section{INTRODUCTION}

Kelantan is located in northeastern of peninsular Malaysia, facing the South China Sea and is bordered by Thailand. Average area of Kelantan state is around 15,099 square kilometers with total population 1,459,994 in 2010. (DOE, 2004). Kelantan rich with natural recourses form unexplored forests and mineral such as petroleum. It is also an attraction to local and international tourists because of the traditional culture. Most of them attract to coastal area along Kelantan as their accommodation site because in this area less of development and villages still maintain traditional lifestyle especially fisherman and batik makers.

Most popular coastal along Kelantan such as Cahaya Bulan Beach located in Kota Bharu, Sri Tujuh Beach in Tumpat and Irama Beach in Bachok. Coastal zone along Kelantan is valued for their communities in term of ecological, economic and culture significant. Fishing, production of salted fish, anchovy sauce and fish cracker are include in coastal economic sector. It is source of income for local people.

Along with the times, the coast of Kelantan also not spared from the problem of coastal water pollution caused by human activity.

Industrial and domestic effluents, agricultural run-off, acid rain, mine drainage has all contributed to some extent to the metal loads in water bodies. Metals are of special concern because they are non degradable and therefore persistent (Bhole and Ramteke, 2011; Chintana, 2002). There are five popular beaches in Kelantan has been studied to evaluate the concentration of heavy metal shown as Fig. 1, which are Sri Tujuh Beach (PST) located in Tumpat, Cahaya Bulan Beach (PCB) and Sabak Beach (PB) in Kota Bharu, Irama Beach (PI) in Bachok and Bisikan Bayu Beach (PBB) in Pasir Putih. This location has selection has according to density of population, social-economic and others factor such as distance to industries area, fish farming area and tourism area.

Corresponding Author: Rizki Wannahari, Departement of Environmental Technology, Faculty of Agro Based Industry, Jeli Campus, Universiti Malaysia Kelantan, Locked bag 100, 17600, Jeli, Kelantan, Malaysia 


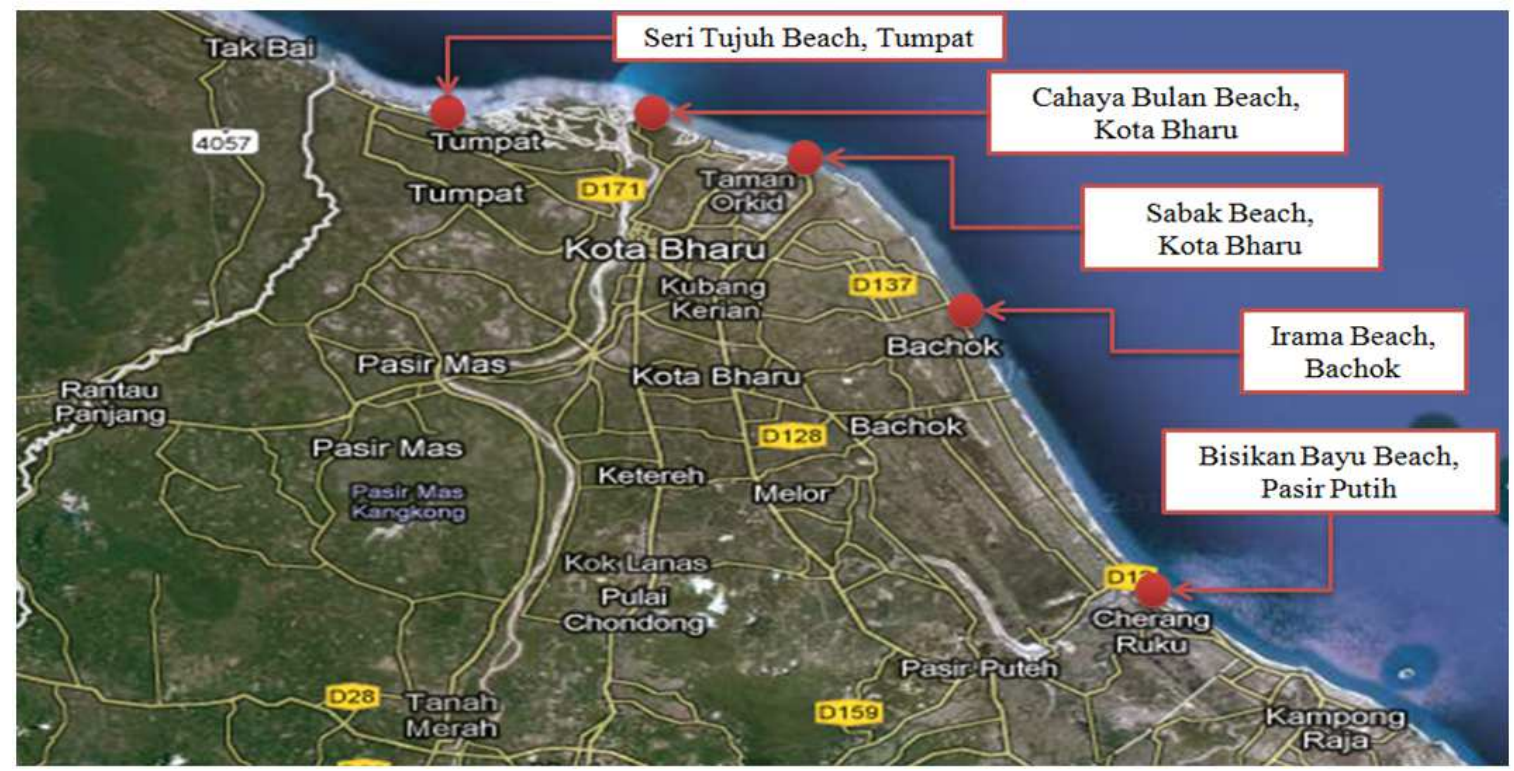

Fig. 1. Sampling location along Kelantan coast

\section{MATERIALS AND METHODS}

The coastal water was collected from five sampling sites along Kelantan Coast, Malaysia during July 2011 until May 2012 while the data from previous years (1996 to 2010) was collected from Department of Environment (DOE) Malaysia (DOE, 2004).

The collected coastal water samples from five beaches were transferred to the Chemical Laboratory of Universiti Malaysia Kelantan after conserve in plastic bottle and treated with nitric acid with a concentration 1 $\mathrm{ml} / 1 \mathrm{~L}$. The four metals which are Cadmium $(\mathrm{Cd})$, Cupper $(\mathrm{Cu})$, Lead $(\mathrm{Pb})$ and Chromium $(\mathrm{Cr})$ were analyzed using Inductive Coupled Plasma Mass Spectrometry (ICP-MS). The homogenize sample were introduced to ammonium pyrrolidine dithiocarbamatemythyl isobutyl ketone (APDC-MIBK) before analyzed using ICP-MS (AOCS, 2009).

\section{RESULTS AND DISCUSSION}

\subsection{Environmental Parameter}

\subsubsection{Pantai Sri Tujuh}

Sri Tujuh Beach (PST) in Tumpat is located seven kilometer from Kota Bharu (N 6 $6^{\circ} 3^{\prime} 00.0^{\prime \prime}$, E $\left.102^{\circ} 08^{\prime} 00.0^{\prime \prime}\right)$. This beach is resulting from the formation of seven bays. Position in the gulf coast is also making its waters are so calm and suitable for various water sports activities including playing volleyball, swimming or camping. The main source of income population of this area is fishing and farming cage fish. Other than selling fresh fish, they also produce salted fish for local and foreign market. From this research known, the average temperature of this coastal water during July 2011 to May 2012 is $30.7^{\circ} \mathrm{C}$, salinity is $32 \mathrm{ppt}$, Dissolved Oxygen (DO) is $5.18 \mathrm{mg} \mathrm{L}^{-1}$ and $\mathrm{pH}$ is about 8.22 .

\subsubsection{Cahaya Bulan Beach}

Cahaya Bulan Beach (PCB) is the beach stretches to about $1.2 \mathrm{~km}$ it located in Kota Bharu (N 6¹0'45.0", E $\left.102^{\circ} 16^{\prime} 50.0^{\prime \prime}\right)$. It is popular because of their traditional product such as Batik, Songket and kites. The temperature of this coastal water during July 2011 to May 2012 is about $30.8^{\circ} \mathrm{C}$, salinity is $35 \mathrm{ppt}$, Dissolved Oxygen (DO) is $5.5 \mathrm{mg} \mathrm{L}^{-1}$ and $\mathrm{pH}$ is about 8.04 .

\subsubsection{Sabak Beach}

Sabak Beach also located in Kota Bharu (N $6^{\circ} 10^{\prime} 25.0^{\prime \prime}$, E $\left.102^{\circ} 20^{\prime} 10.0^{\prime \prime}\right)$. This beach is not too popular but this beach is selected in this study because it located near industrial place which is Pengkalan Chepa so it high potential to be polluted. The temperature of this coastal water during July 2011 to May 2012 is about $30.82^{\circ} \mathrm{C}$, salinity is $29.66 \mathrm{ppt}$, Dissolved Oxygen (DO) is $6.73 \mathrm{mg} \mathrm{L}^{-1}$ and $\mathrm{pH}$ is about 8.05 (Table 1). 
Rizki Wannahari et al. / American Journal of Environmental Science 9 (6): 505-510, 2013

Table 1. Chemical and physical parameter of Kelantan Coastal Water

\begin{tabular}{lllllll}
$\begin{array}{l}\text { Coastal } \\
\text { Water }\end{array}$ & $\begin{array}{l}\text { Temperature } \\
{ }^{\circ} \mathrm{C}\end{array}$ & $\begin{array}{l}\mathrm{DO} \\
\mathrm{mg} / 1\end{array}$ & $\mathrm{Ph}$ & $\begin{array}{l}\text { Turbidity } \\
\mathrm{g} / 1\end{array}$ & $\begin{array}{l}\text { conductivity } \\
\mathrm{mS} / \mathrm{cm}\end{array}$ & $\begin{array}{l}\text { Salinity } \\
\mathrm{ppt}\end{array}$ \\
\hline PBB & 30.72 & 5.18 & 8.22 & 32.19 & 54.38 & 32.18 \\
PI & 30.69 & 6.27 & 7.82 & 30.68 & 52.05 & 30.55 \\
SB & 30.82 & 6.73 & 8.05 & 31.32 & 50.40 & 29.66 \\
PCB & 30.83 & 5.50 & 8.04 & 29.58 & 49.51 & 35.35 \\
PST & 31.70 & 6.39 & 8.03 & 27.75 & 48.33 & 27.34 \\
\hline
\end{tabular}

Note: Average value of parameters, collected from July 2011 to May 2012

\subsubsection{Irama Beach}

Irama Beach located in the district of Bachok about $25 \mathrm{~km}$ south of Kota Bharu (N 603'00.0", E $\left.102^{\circ} 25^{\prime} 15.0^{\prime \prime}\right)$. It attracts visitors, especially on weekends, visitors often come here are from locals. The temperature of this coastal water during July 2011 to May 2012 is about $30.69^{\circ} \mathrm{C}$, salinity is $30.55 \mathrm{ppt}$, Dissolved Oxygen (DO) is $6.27 \mathrm{mg} \mathrm{L}^{-1}$ and $\mathrm{pH}$ is about 7.82 .

\subsubsection{Bisikan Bayu Beach}

Last is the Bisikan Bayu Beach (N 5 $52^{\prime} 00.0^{\prime \prime}, \mathrm{E}$ $\left.102^{\circ} 31^{\prime} 00\right)$. This is one of the popular beach for local visitor because not only beautiful, this beach is also near with jetty and famous with the fresh fish. The temperature of this coastal water during July 2011 to May 2012 is about $30.72^{\circ} \mathrm{C}$, salinity is $32.18 \mathrm{ppt}$, Dissolved Oxygen (DO) is $5.18 \mathrm{mg} \mathrm{L}^{-1}$ and $\mathrm{pH}$ is about 8.22 .

\subsection{Analysis Concentration}

The Heavy metals can enter and contaminate the coastal waters from feeder rivers and from direct discharges and once there, they can be trapped and accumulated in sediments or be directly captured by living organisms. Their negative effect is not only by decreasing aquatic species diversity but by exposing human beings to these xenobiotics directly through the food chain, with a potential danger to human health. Because this valid effect, the coastal water monitoring programme in Malaysia has started since 1978 until today by the Department of Environmental (DOE) Malaysia. In Kelantan, DOE monitoring of the coastal and marine water has done in once a year. Using the previous data from DOE and the recent data from this research, the evaluation of the coastal water of Kelantan can be done to determine the quality of coastal water in selected beach in Kelantan.

\subsection{Cadmium}

From the Fig. 2 below, it can be seen if the concentration of cadmium is below the DOE standard in most of the year. The critical level is in 2003 to 2006, where the concentration of cadmium in five beaches was out of standard. But by 2008 until May 2012, the concentrations seem to be neutralized and tend to be normal.

\subsection{Cupper}

The concentration of Cupper $(\mathrm{Cu})$ during 1996 until May 2012 has shown a same pattern like the concentration of cadmium. As shown in Fig. 3, year 2003 to 2006 has a critical level of cupper, where the value of cupper has exceed the concentration standard of cupper provide from DOE. Further study is needed to understand the cause of increasing cupper and cadmium during year 2003 to 2006 in selected Kelantan coastal water. After 2006, the concentration values of cupper tend to be decrease to the normal level until May 2012.

\subsection{Lead}

Figure 4 shown the high concentration of lead $(\mathrm{Pb})$ in five selected beach in Kelantan during 1996 until May 2012. During the times, there are several years shown the critical level of lead in five selected beach in Kelantan. In these years the value of lead concentration has exceed the limit of standard. In the industrial, organic lead usually is applied in petroleum production while the inorganic lead compounds are applied for battery and paint production. The high value of lead concentration in Kelantan coastal water is needed to be study further to determine the source of contamination and the effect of contamination.

\subsection{Chromium}

Figure 5 shown the concentration of chromium in five selected beach in Kelantan was under the limit standard according to DOE in most of the year. There are increasing concentration in July 2012 and November 2012, but the concentration has tend to be normal for the next month; January 2012 to May 2012. 
Rizki Wannahari et al. / American Journal of Environmental Science 9 (6): 505-510, 2013

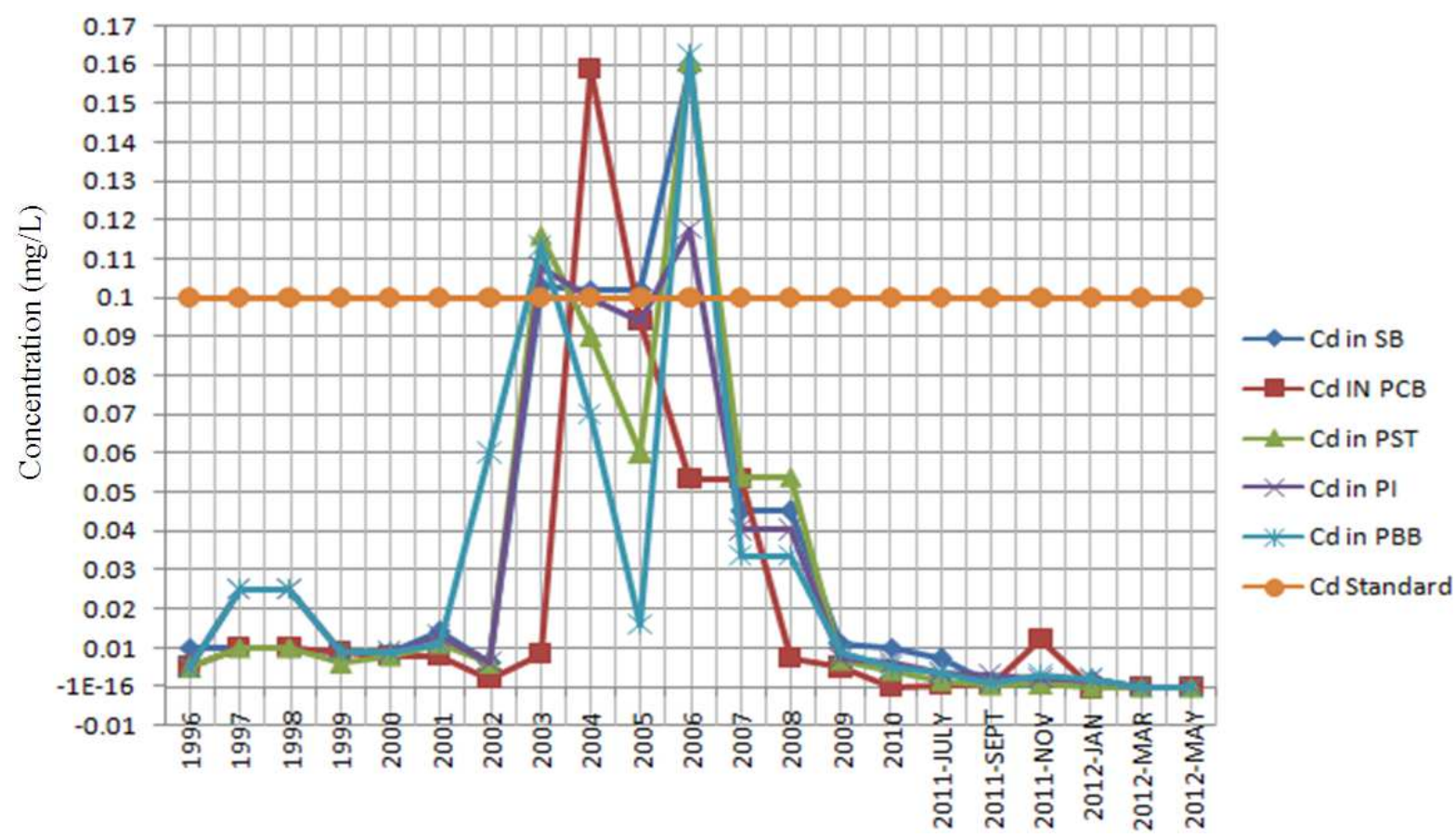

Fig. 2. Evaluation of Cadmium $(\mathrm{Cd})$ concentration in Kelantan coastal water

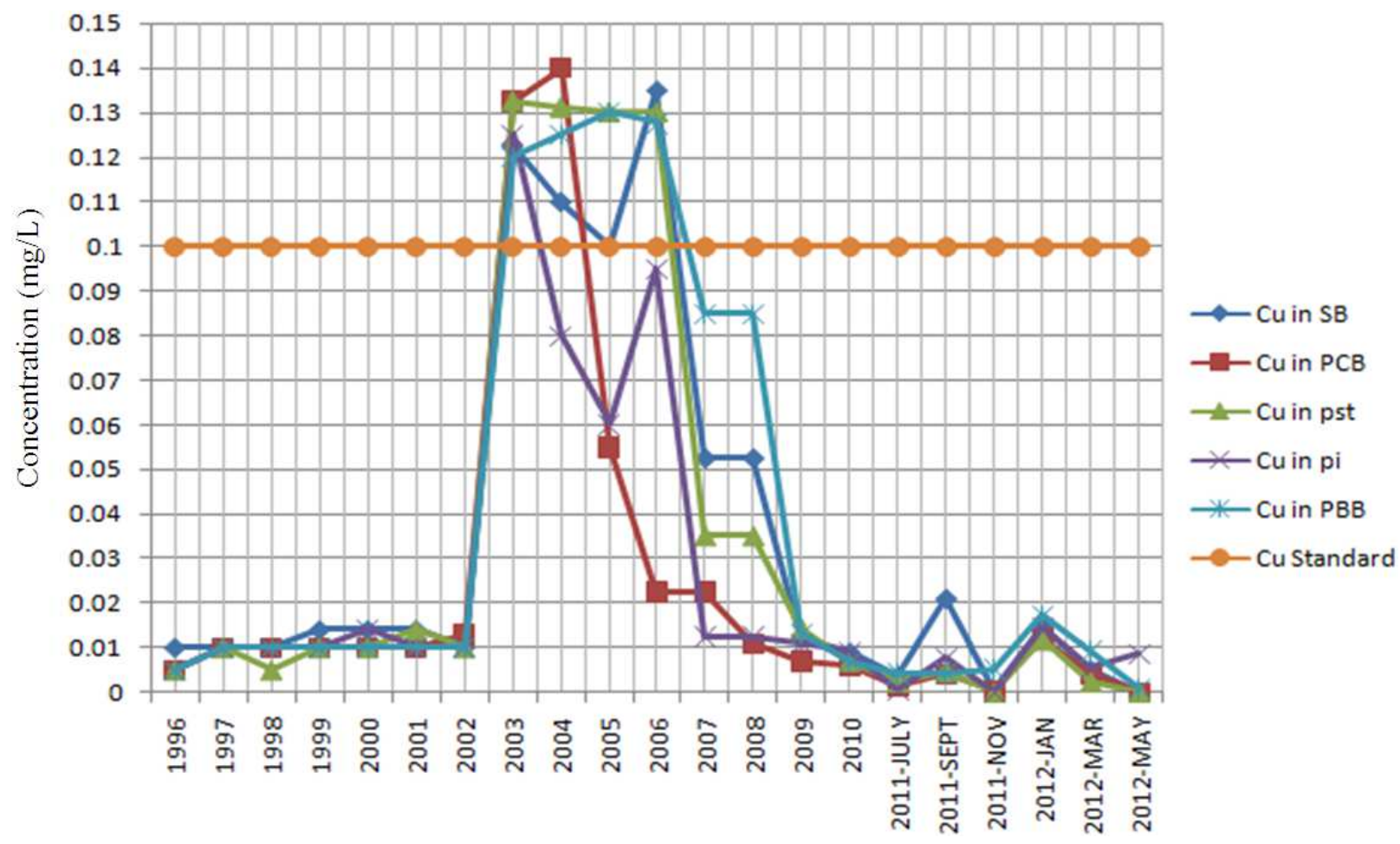

Fig. 3. Evaluation of Cupper $(\mathrm{Cu})$ concentration in Kelantan coastal water 


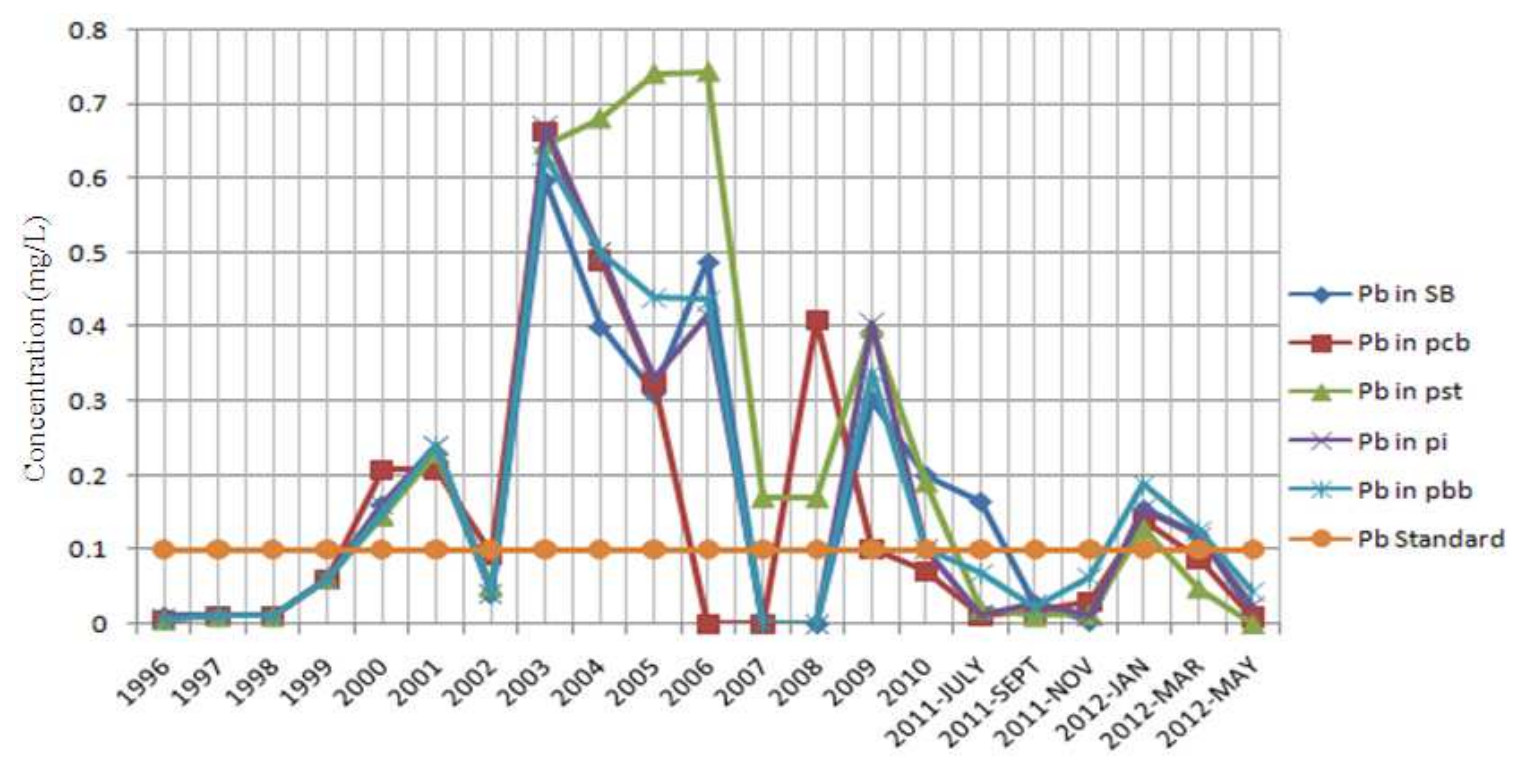

Fig. 4. Evaluation of Lead $(\mathrm{Pb})$ concentration in Kelantan coastal water

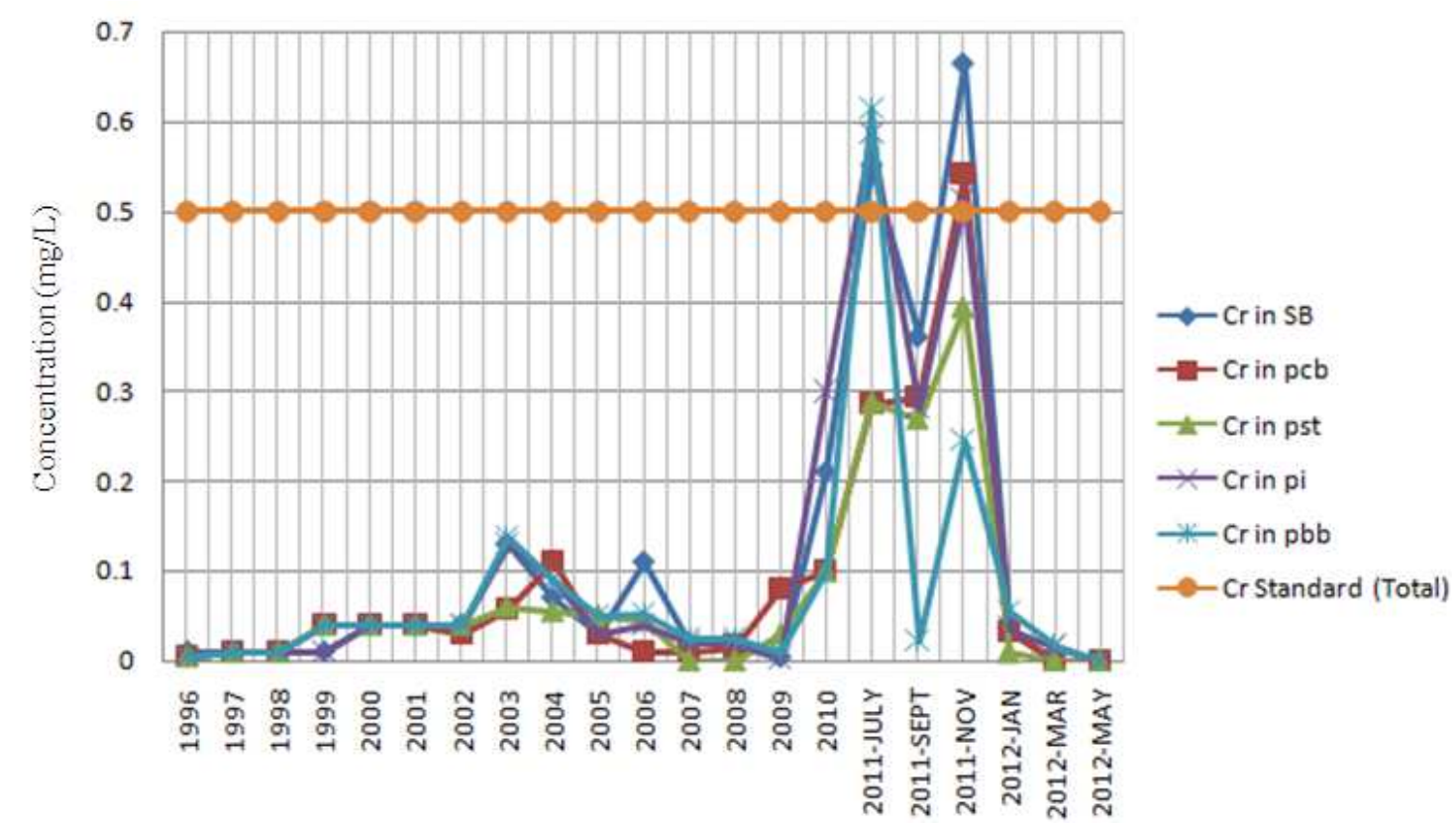

Fig. 5. Evaluation of Chromium (Cr) concentration in Kelantan coastal water

\section{CONCLUSION}

Most of the year, the concentration of Cadmium (Cd), Cupper $(\mathrm{Cu})$ and Chromium $(\mathrm{Cr})$ in the five selected beach; Sri Tujuh Beach (PST), Cahaya Bulan Beach (PCB), Sabak Beach (PB), Irama Beach (PI) and
Bisikan Bayu Beach (PBB) along Kelantan was in Department of Environment (DOE), Malaysia limit standard. The critical value was founded in lead concentration, the result shown the high concentration of lead in the five selected beach in Kelantan during the research time. This phenomenon is needed to be further 
studied to avoid the possibility the effect of lead contamination in the future.

\section{ACKNOWLEDGEMENT}

This research was financially supported by the Fundamental Research Grant Scheme (FRGS) No. R/FRGS/A03.00/00413A/002/2011/000051 and also collaborate with Department of Environmental (DOE) Kelantan, Malaysia.

\section{REFERENCES}

AOCS, 2009. Official Methods and Recommended Practices of the AOCS. 6th Edn., USA.
Bhole, V. and D.S. Ramteke, 2011. Preferential adsorption of heavy metals on activated carbon. Bangladesh J. Sci. Indus. Res., 46: 211-218. DOI: 10.3329/bjsir.v46i2.2572

Chintana, S., 2002. Removal of heavy metal from waste water by adsorption using chitosan. Suranaree University of Technology, Thailand.

DOE, 2004. Malaysian environmental quality report 2004. Strategic Communications Division Publication Section. Department of Environment, Malaysia. 